\title{
Corporate Governance: Voluntary, Mandatory or a Hybrid Approach?
}

\author{
Chih Khiam Ping ${ }^{1} \&$ Tan Seng Teck ${ }^{2}$ \\ ${ }^{1}$ CEO, Techtics Pro Sdn Bhd, Malaysia \\ ${ }^{2}$ Senior Lecturer, Faculty of Business, Communication and Law (FOBCAL), INTI International University, \\ Malaysia \\ Correspondence: Tan Seng Teck, Faculty of Business, Communication and Law (FOBCAL), INTI International \\ University, Malaysia.
}

Received: November 10, 2019

Accepted: December 10, 2019 Online Published: December 25, 2019

doi:10.5539/ibr.v13n1p233

URL: https://doi.org/10.5539/ibr.v13n1p233

\begin{abstract}
This paper addresses a dilemma in corporate governance. Indeed, corporate governance has been a hype in modern business world. They were designed to curb malpractices and foul play in corporations. However, many practitioners and academics alike have not come in terms for the best approach for corporate governance. This paper simplistically addresses this dilemma and examine briefly the varying approaches to corporate governance in modern business world. This is not an empirical piece but on the contrary it is a writing that address the intricate dilemma in corporate governance and perhaps to determine the trajectory of their future directions.
\end{abstract}

Keywords: corporate governance, voluntary, mandatory, hybrid

\section{Introduction}

In today's face-pace and competitive business environment, being a good corporate citizen is about embracing good corporate governance. A company that aims at fair and proper disclosure, best business practices and accountability is deemed a good steward, and will win the trust and confidence of the industry partners and stakeholders. To stay sustainable is to adopt fair practices, mechanisms and initiatives that will align with the interests of stakeholders.

Academia as well as industry experts deliberated on the phrase corporate governance; however, no one universally agreed definition for it. Kimber, D., Lipton, P. \& O'Neill, G. (2005) suggested that corporate governance is a combination of legal and statutory system that builds the structure and role of corporation's board, at the same time defines the rights and duties of management and stakeholders. The Malaysian Code on Corporate Governance 2012 (MCCG 2012) and subsequently the MCCG 2017 offer a definition "the process and structure used to direct and manage the business and affairs of the company towards enhancing business prosperity and corporate accountability with the ultimate objective of realizing long-term shareholder value, whilst taking into account the interests of other stakeholders." In short, corporate governance is about good processes and structures that drive the long-term sustainability of a corporation, taking into account the holistic welfares of those directly or indirectly connected to the corporation.

Historically, firms are subject to a set of rules and initiatives that prescribes acceptable corporate behavior. In the USA, a report entitled 'The Role and Composition of the Board of Directors of the Large Publicly Owned Corporation' was the first guidelines drafted in January 1978 by the Business Roundtable in an attempt to improve governance in US corporations (see Monks \& Minow, 1992). Slowly, other countries saw the need to have a code of good governance, and the early 90s saw the rapid development of it. According to Davis \& Thompson (1994), there has been an exponential development in the adoption of governance codes throughout the world, particularly since the publication of the Cadbury Report in 1992 in the UK. Towards the end of 1999, some 24 countries (industrialized and developing) had issued at least one code of good governance, bringing 72 codes of good governance around the world (Aguilera \& Cuervo-Cazurra, 2004).

However, the collapse of major corporations in the world in the early 2000s has sparked off hot debates concerning the need to tighten corporate governance mechanisms and implement mandatory regulations. High profile scandals which mostly involved accounting fraud and false or inadequate disclosure, for examples, the fall of Enron and WorldCom in the US, HIH Insurance Group and Ansett in Australia, Griffin Trading and Universal Bulk Handling in the UK, that led to widespread unemployment and bankruptcies. Compounded by 
the Asian Financial Crisis (AFC) in 1997 that have affected the economies of many countries, particularly that of Indonesia, Thailand, South Korea, Malaysia and the Philippines, have highlighted the serious lack of corporate governance practices in these countries. Even though no consensus as to the cause of AFC, academics were of opinion that fundamental weaknesses involving regulatory institutions and the lack of sensible monitoring were the key matters (Alba, Claessens \& Djankov 1998; Claessens, Djankov \& Lang 2000). It has led to the increased urgency of adhering to corporate governance principles.

In recent years, the debate has been ongoing: whether corporate governance should be voluntary or mandatory. While it is generally agreed that no one size fits all in the intricate yet delicate world of corporate governance, many firms have been proactive in designing their own practices, within acceptable limits, to ensure continued confidence and trust from stakeholders. It is undeniable that good corporate governance practices will not only benefit investors but also enhances the sustainability and value of the firms.

This paper attempts to examine and assess the two existing approaches of corporate governance. The question remains: Would a regime that is mandatory or voluntary be optimal, or would a mandatory system be beneficial? The responsibility of companies is to provide investors with adequate disclosure, which implies adequate checks on management, financial and board control. A mandatory approach may protect investors and boost their confidence in the firm. However, it may be too stifling on the firm's initiatives. Perhaps, it should be assumed that most firms inevitably want to enhance their stakeholders' value and trust, and will seek out incentives to achieve this need. They would adopt best practices voluntarily, if this realization steers them on to reap the economic benefits of increased access to external financing, lower cost of capital, reduced risk of financial problems, and higher operational performance. Corporate rules or mechanisms should be largely enabling and should be seen as guidelines rather than strict laws.

This paper maintains that extreme ends of the regime may not work to the benefit of both firms and stakeholders, and a more accommodative regime that takes into account the benefits and costs of stakeholders and firms, should be adopted. To comply may not ensure accountability, whereas to be accountable will inevitably generate a higher level of compliance. Firms have incentives to adopt enhanced governance practices voluntarily and to make disclosure about the same. An optimal governance regime is a hybrid one in which adoption of best practice guidelines is voluntary but disclosure of corporate governance practices is mandatory. Such a regime is optimal because it balances the benefits and costs to all stakeholders, particularly issuers and investors. A partially mandatory structure minimizes costs but encourages compliance is optimal.

\section{The Resurgence of Corporate Governance}

The principal objective of corporate governance is accountability; transparency, predictability and participation are secondary but should not be overlooked. Over the years, international crises and controversies have pointed to the need for a tighter corporate governance practice, and urgent reforms needed to revive and protect stakeholders' interest, trust and confidence in the firms.

The Global Financial Crisis (GFC) in 2008 has propelled the demand for a scrutiny on corporate governance worldwide. Despite the active promotion of corporate governance reforms post-AFC, major fault lines remain (Rajan 2011; Lang \& Jagtiani 2010). Against this shattering scene of crises, collapses and uncertainty, corporate governance has assumed a stricter and if not, stronger shade than before. For instance, in Malaysia, the GFC has alerted companies to address failed government control and assess reforms that will put corporations back in power, economically and financially. Along with other Asian governments, Malaysia companies have become increasingly aware of the need for a sound corporate governance framework if they were to remain attractive to investors. Hence, changes in regulatory practices are crucial. There should be proactive efforts to prevent the recurrence of corporate collapses, scandals and fraud.

\section{The Dominant Approaches: Mandatory and Voluntary}

The dominant approaches to corporate governance have been mandatory and voluntary. In Australia, corporations are governed by binding and non-binding rules, and there has been debate on 'hard law' versus 'soft law' (Zadkovich 2007). 'Hard law' refers to what is mandatory. Mandatory implies compliance and failure to do so would result in sanctions. This approach implies compulsion to comply. 'Soft law', on the other hand, refers to voluntary practice of corporate governance regulations, and freedom implied in this voluntary approach. Interestingly, like most other countries, Australia and Malaysia tend to move in favor of a hybrid approach, that is, one that espouses neither purely mandatory nor purely voluntary regimes. Instead, a "hybrid" incorporates both aspects of the voluntary and mandatory, where there is a delicate fusion of mandatory regulations and voluntary rules and conduct. 
The traditional regime for corporations is a code of rules and practices that prescribe acceptable behavior and conduct, and any trace of non-compliance will result in penalties. This instills fear; for example, Australia's Corporations Act 2001 contains various provisions that detailed all aspects of a company's corporate behavior and arrangements. This Act ensures internal procedures; stock transactions and directors' duties and responsibilities are under strict adherence. Similarly, in Malaysia where the government exercises full control over the practices of corporations, and hold a powerful hand in influencing the corporations' arrangements such as disclosure requirements, accounting standards and management issues. Evidently, the common law has a critical role in setting the standard and pace of corporate governance. In the US, the collapse of Enron and WorldCom raised the question of full compliance or partial compliance. The preference was for flexibility rather than a prescriptive code.

There is always a need for caution in implementing an approach that will benefit both corporations and investors. Too harsh an approach may stifle both parties, and may work the reverse in terms of economic interests. On the other hand, a mandatory regime may send a solid message to the world that investors are serious and that corporations are serious partners in this venture. In the early years following the era of crisis, a mandatory regime may be beneficial in rebuilding lost confidence and shaking complacent minds. It ensures minimum standards are met, and this would in turn ensure strong investor protection and more sustainable capital markets. A voluntary approach seen to be vague and less affirming when it comes to investor protection. In a voluntary regime, corporations allowed to set their own terms of reference, and this may reduce certainty for investors about the corporation's compliance. However, this should not be taken as the norm but needs to be appraised on its relevance and appropriateness in an age where corporations need a more dynamic form of engagement with investors instead of merely adhering to a strict corporate governance code. Besides, the issue of increasing cost may not work to the benefit of the government, corporations and investors.

\section{Towards a Hybrid Regime}

A hybrid system is often described as a type of enforced self-regulation (Du Plessis et al., 2005). It may be perceived as allowing more flexibility and discretion to corporations, and aims at a symbiotic relationship between the mandatory and voluntary approaches. The Australian Securities Exchange (ASX) Principles of Good Corporate Governance and Best Practice recommendation is an example of such a system. There are 10 principles in this code, but these are just guidelines rather than rules. It is to ensure best practice for optimal performance and accountability. In other words, it follows the principle of "comply or explain" and is far from being strictly mandatory.

Perhaps what is needed is not so much of whether to implement a mandatory code or not; it is to ensure that an effective system is designed that is appropriate to investors and corporations. As such, a hybrid system that combines both the mandatory and voluntary aspects will be less cost consuming, and allow corporations more space and independence to exercise corporate discretion. Corporations are more likely to adopt a more flexible system rather than subscribing to a regime that compels them to adhere blindly and fearfully. Voluntary disclosure should be allowed, and as long as corporations meet investors' needs and requirements in terms of information and portfolios, a mandatory code for forced disclosure ceases to be relevant.

A flexible and symbiotic hybrid approach will cater to the varied sizes of corporations. Smaller firms may welcome this regime as their activities may not be that high to warrant the principles or rules listed, and have the option to disclose information. However, by adopting a hybrid regime, reporting regulations will still ensure that smaller corporations adhere to minimum standards of reporting.

There is always doubt as to whether any system is effective. No one system fits all, and no one system is crisis-proof. What matters is whether the system is flexible, feasible and pragmatic. It should be a system that works to the advantage of not just bigger and established corporations but also newcomers in the industry whose level of profitability may not be as high as the existing ones, and thus certain provisions or regulations may be less relevant to them. The regulators and the state must lead by example in ensuring proper governance framework is adhered to and be respected.

\section{Conclusion}

It is evident, from the above discussion, that there is a need to move away from a restrictive mandatory regime to a more flexible and open approach. For any system to be effective, corporations and investors should be engaged sufficiently, and honest management should be the underlying goal of all. So far, the new corporate governance regime of Australia is proof that stakeholders and corporations are departing from what used to be forced upon them, and shaking off such mandatory demands. In the case of Malaysia, the government continues to exert powerful control over corporations, and sometimes it borders on compulsion. Nevertheless, not all is negative; 
there is a concerted move towards reducing the concentration of power from the government and redesigning a more effective system of checks and balances. In essence, the most effective corporate governance regime is one that expands, encourages and promotes, rather than one that hinders, limits and discourages. It is not a shield against crisis as to err is human. What matters in the final analysis is the degree of risk involved, and the extent of control over human error and the business environment. The form should not take precedence over the essence, which lies in the sustainability of corporations and the collaboration with stakeholders. Perhaps, what is more significant would be the initiation of more open dialogues and honest consultation between corporations and stakeholders. In the realm of business, it is not about codes, rules or regimes; it is the dynamic interplay of trust and openness that will steer all business parties in the right direction. In brief, good corporate governance extends beyond the book of rules. It is essentially about honest engagement.

\section{References}

Aguilera, R. V., \& Cuervo-Cazurra, A. (2004). Codes of good governance worldwide: What is the trigger? Organization Studies, 25(3), 415-443. https://doi.org/10.1177/0170840604040669

Alba, P., Claessens, S., \& Djankov, S. (1998). Thailand's Corporate Financing and Governance Structures. Washington, DC: World Bank Publications. https://doi.org/10.1596/1813-9450-2003

Claessens, S., Djankov, S., \& Lang, L. (2000). The Separation of Ownership and Control in East Asian Corporations. Journal of Financial Economics, 58(1-2), 81-112. https://doi.org/10.1016/S0304-405X(00)00067-2

Davis, G. F., \& Tracy, A. T. (1994). A social movement perspective on corporate control. Administrative Science Quarterly, 39, 141-173. https://doi.org/10.2307/2393497

Du Plessis, J., McConvill, J., \& Bagaric, M. (2005). Principles of contemporary corporate governance. Cambridge University Press, Melbourne. https://doi.org/10.1017/CBO9780511813481

Kimber, D., Lipton, P., \& O’Neill, G. (2005). Corporate governance in the Asia Pacific region: A selective review of developments in Australia, China, India and Singapore. Asia Pacific Journal of Human Resources, 43(2), 180-197. https://doi.org/10.1177/1038411105055057

Lang, W., \& Jagtiani, J. A. (2010). The Mortgage and Financial Crises: The Role of Credit Risk Management and Corporate Governance. Atlantic Economic Journal, 38(3), 295-316. https://doi.org/10.1007/s11293-010-9240-4

Monks, R. A. G., \& Nell, M. (1992). Power and accountability: Restoring balance of power between corporations, owners and societies. New York: Harper Business.

Rajan, R. (2011). Fault Lines: How Hidden Fractures Still Threaten the World Economy. Princeton, NJ: Princeton University Press. https://doi.org/10.1515/9781400839803

Zadkovich, J. (2007). Mandatory Rules and 'Please Explain': A corporate governance quagmire. Deakin Law Review, 2(2), 23-39. https://doi.org/10.21153/dlr2007vol12no2art217

\section{Copyrights}

Copyright for this article is retained by the author(s), with first publication rights granted to the journal.

This is an open-access article distributed under the terms and conditions of the Creative Commons Attribution license (http://creativecommons.org/licenses/by/4.0/). 